\title{
Effect of the entomopathogenic fungus, Metarhizium anisopliae (Metschnikoff) Sorokin, on demographic fitness of the tomato leaf miner, Tuta absoluta (Meyrick) (Lepidoptera: Gelechiidae)
}

\author{
Maryam Alikhani ${ }^{1}$, Seyed Ali Safavi ${ }^{1 *}$ and Shahzad Iranipour ${ }^{2}$
}

\begin{abstract}
The aim of the present study was to determine the deleterious effects of the entomopathogenic fungus, Metarhizium anisopliae (isolate DEMI 001), on biological and population parameters of the tomato leaf miner, Tuta absoluta (Meyrick) (Lepidoptera: Gelechiidae), offspring arising from treated third-instar larvae. The results revealed that the duration of immature stages (egg to adult emergence) in the F1 generation was significantly affected by sub-lethal concentration $\left(\mathrm{LC}_{10}, \mathrm{LC} \mathrm{C}_{20}\right.$, and $\left.\mathrm{LC} \mathrm{C}_{30}\right)$ and increased in all treatments than the control. In addition, the longevity of moth adults and fecundity of females developed after the fungus-treated larvae were significantly affected. The intrinsic and finite rates of increase ( $r_{m}$ and $\lambda$, respectively) decreased by increasing the conidial concentration. However, the mean generation time ( $T$ ) and doubling time (DT) were high in insect treatments. The findings clarified adverse effects of $M$. anisopliae (isolate DEMI 001) treatment on the demographic fitness of T. absoluta in the next generation.
\end{abstract}

Keywords: Tuta absoluta, Metarhizium anisopliae, Deleterious effects, Demographic fitness, Life-table parameters

\section{Background}

The pinworm (leaf-miner), Tuta absoluta (Meyrick) (Lepidoptera: Gelechiidae), is considered one of the key pests of tomato (Lycopersicon esculentum) in many parts of the world (Tropea-Garsia et al. 2012 and Zappala et al. 2013). T. absoluta larvae are hidden inside different parts of leaves, stems, shoots, and flowers of host plants (Lee et al. 2014). This feeding behavior allowed the pest to be safe from chemical insecticides. Moreover, developing resistance to insecticides and the side effects of chemicals on inoculation and conservation of biological control agents have led to the use of other methods to control the pest (Urbaneja et al. 2012). Consequently, employing environmentally safe techniques such as entomopathogenic fungi (EPF) has a great potential for use in different biocontrol strategies (Butt et al. 2001 and Goettel et al. 2005). The

\footnotetext{
*Correspondence: a.safavi@urmia.ac.ir; s.a.safavi@gmail.com ${ }^{1}$ Department of Plant Protection, Faculty of Agriculture, Urmia University, Urmia, Iran

Full list of author information is available at the end of the article
}

muscadine fungus, Metarhizium anisopliae (Metschnikoff) Sorokin, is an important EPF, which has been a long-standing model to study biological control of pest insects by fungi (Zimmermann 1993). It was the first fungus to be globally mass produced and utilized for insect pest control (Roberts and St Leger 2004).

$M$. anisopliae has been documented as pathogenic to eggs (Pires et al. 2009), larvae (Tadele S and Emana 2017), and pupae (Contreras et al. 2014) of T. absoluta. Giustolin et al. (2001) indicated that application of EPF, Beauveria bassiana, on tomato was effective in integrated management of T. absoluta larvae contributor with a resistant genotype. Furthermore, González-Cabrera et al. (2011) documented high susceptibility of the tomato borer larva to Bacillus thuringiensis toxins. Similarly, Batalla-Carrera et al. (2010) indicated that the late larval instars of the tomato leaf miner were highly susceptible to entomopathogenic nematodes.

Life table population studies are substantial for successful biological control programs, since they include full 
comprehension of the survival, development, and reproduction of a species (Tuan et al. 2015). The intrinsic rate of increase $\left(r_{m}\right)$ is a principal parameter of life table helping the ecologists to understand the establishment of an insect population (Birch 1948). Moreover, it has been indicated that adverse effects of fungal infection can affect the population dynamics of the host and contribute to the status of the target insect as a pest (Blanford and Thomas 2001). Therefore, studies of indirect effects of EPF on life table parameters to manage pests in crops are important. Jarrahi and Safavi (2016) investigated the deleterious effects of $M$. anisopliae (isolate M14) on the fitness cost of Helicoverpa armigera $(\mathrm{Hb}$.). These researchers indicated that different sub-lethal concentrations of fungi had a significant decrease in the F1 population growth of pest. Hajek et al. (2008) observed that the fitness of Anoplophora glabripennis females decreased by horizontal transmission of $M$. anisopliae to offspring. Because no research was carried out exploring the effect of EPF on fitness cost of the tomato leaf miner, the present study aimed to evaluate deleterious effects of $M$. anisopliae (isolate DEMI 001) on development, survival, and fecundity of $T$. absoluta in progeny derived from third-instar larvae exposed to EPF.

\section{Materials and methods}

\section{Plant cultivation}

Tomato seeds (Super luna cultivar) were planted in a nursery in 100 cell foam trays and kept under greenhouse conditions $\left(25^{\circ} \mathrm{C}, 16 \mathrm{~L}: 8 \mathrm{D}-\mathrm{h}\right.$ photoperiod and 65 $\pm 5 \%$ R.H.). After 2 weeks, plants were transplanted in plastic pots $(2 \mathrm{l})$, filled with a soil to peat moss to sand mixture (2:1:1). Then, after 45 days, the seedlings were used in rearing wooden cages $(60 \times 60 \times 40 \mathrm{~cm})$ for feeding and oviposition of T. absoluta.

\section{Insect rearing}

A culture of $T$. absoluta was initiated by collecting infected leaves from tomato fields in Urmia, West-Azerbaijan Province, Iran. The insects were reared on tomato plants for two generations in a controlled environment glasshouse $\left(25^{\circ} \mathrm{C}, \quad 16 \mathrm{~L}: 8 \mathrm{D}-\mathrm{h}\right.$ photoperiod and $65 \pm 5 \%$ R.H.). To obtain a cohort of the age-synchronized of insects, tomato borer adults (20-25 pairs) were enclosed in rearing wooden cages containing 45 day-old tomato and allowed to egg laying. After $24 \mathrm{~h}$, adults of T. absoluta were removed and the plants were kept under greenhouse conditions. After an appropriate time period, the larvae were collected and utilized in the experiments.

\section{Fungal inoculum}

After performing a bioassay to determine the susceptibility of early third-instar T. absoluta larvae to various isolates of $M$. anisopliae, a DEMI 001 isolate from
Rhynchophorus ferrugineus was selected and used. These isolates were prepared at the laboratory of the Plant Protection Department of Urmia University.

Consequent to the passage of the fungus through $T$. absoluta, it was cultured on Sabouraud dextrose agar with 1\% yeast extract (SDAY) in Petri dishes (diameter $6 \mathrm{~cm}$ ). Subsequently, for complete sporulation, the cultures were incubated for 14 days at $25^{\circ} \mathrm{C}$. Fungal suspensions were prepared in distilled water containing $0.02 \%$ Tween- 80 and spore concentration was determined, using a Neubauer hemocytometer. The viability of the conidia was determined by inoculating plates of SDAY (four plates) with a conidial suspension $\left(100 \mu \mathrm{l}\right.$ of $10^{7}$ dilutions), which was then incubated for $24 \mathrm{~h}$ at $25^{\circ} \mathrm{C}$. Conidia were considered viable when the germ tube lengths corresponded to the width (Inglis et al. 2012). The viability of conidia was assessed immediately before estimation of each experiment and the percentage viability of conidia in the various tests at $>95 \%$.

\section{Bioassays}

Experiments were carried out, using third-instar larvae of $T$. absoluta. Based on the results of a preliminary experiment, five spore concentrations $\left(10^{3}, 10^{4}, 10^{5}, 10^{6}, 10^{7}\right.$ conidia $\left.\mathrm{ml}^{-1}\right)$ were prepared from the stock suspension. Separated batches of third-instar larvae were immersed in $5 \mathrm{ml}$ of the respective suspensions for $10 \mathrm{~s}$. The insects were transferred on tomato leaves fitted in Petri dishes $(10 \mathrm{~cm}$ diameter) in the lid covered with fine mesh gauze for ventilation and fresh tomato leaves were provided daily. The control group was treated by sterile distilled water plus $0.02 \%$ Tween-80. Mortality rate was monitored daily and any infected larvae with $M$. anisopliae (DEMI 001) were removed. Larval cadavers were surface sterilized in $70 \%$ ethanol, followed by sterile distilled water and incubated on moist filter paper in Petri dishes $(6 \mathrm{~cm}$ diameter $)$ to confirm infection by $M$. anisopliae. The experiment consisted of four replicates of 15 insects per replicate for each concentration.

\section{Developmental and population parameters (evaluation of sub-lethal effects on fitness cost)}

To evaluate potential fitness costs on the subsequent generations (F1), offspring of moths (100 eggs) that were treated third-instar $T$. absoluta larvae with sub-lethal concentrations $\left(\mathrm{LC}_{10}, \mathrm{LC}_{20}\right.$, and $\left.\mathrm{LC}_{30}\right)$ of the $M$. anisopliae s.l. were used. The eggs $(<24 \mathrm{~h})$ were transferred on tomato leaves by a fine camel hair brush. Observations were taken daily for hatching eggs and emerging larvae. Leaves were regularly replaced by fresh ones. The duration and survivorship 
Table 1 Sub-lethal concentration values of Metarhizium anisopliae s.I. (isolate DEMI 001) on third-instar larvae of Tuta absoluta

\begin{tabular}{lllll}
\hline Sub-lethal concentrations (conidia $\left.\mathrm{ml}^{-1}\right)$ & & $\begin{array}{l}\text { Slope } \\
\pm \mathrm{SE}\end{array}$ & $X^{2}(\mathrm{df})$ & $P$ value \\
\hline $\mathrm{LC}_{10}$ & $\mathrm{LC}_{20}$ & $\mathrm{LC}_{30}$ & & \\
\hline $1.29 \times 10^{3}$ & $6.39 \times 10^{3}$ & $2.03 \times 10^{4}$ & $3.25 \pm 0.04$ & $2.926(3)$ \\
$\left(3.49 \times 10^{2}-3.25 \times 10^{3}\right)$ & $\left(2.41 \times 10^{3}-1.32 \times 10^{4}\right)$ & $\left(9.35 \times 10^{3}-3.81 \times 10^{4}\right)$ & & 0.40 \\
\hline
\end{tabular}

95\% fiducial limits (FL) are shown in parenthesis

of the larval period and subsequent stages were recorded daily. After adult emergence, one pair of newly emerged tomato borer (male and female) were placed in plastic containers $(3.5 \mathrm{~cm}$ diameter and 6 $\mathrm{cm}$ height), and tomato leaflets (the petioles wrapped in moistened cotton), as an oviposition substrate, were placed in daily. Adults were fed by $10 \%$ sugar solution as food. The number of laid eggs was counted daily under a stereomicroscope until the female died.

\section{Statistical analysis}

In order to conduct probit analysis (Finney 1971) of mortality data from bioassays, SPSS software (IBM SPSS Statistics for Windows 2016) was used. Life table parameters including intrinsic rate of increase $(r)$, net reproduction rate $\left(R_{0}\right)$, finite rate of increase $(\lambda)$, gross reproductive rate (GRR), doubling time (DT), and mean generation time $(T)$ were calculated according to Carey (1993). For the estimation of the pseudo-values of these parameters, the Jackknife technique (Maia et al. 2000) was used. In the next step, the obtained pseudo-values were subjected to an analysis of variance. Statistical differences among means were compared using the Student-Newman-Keuls (SNK) test at $P<0.05$. Comparisons of sex ratio among different fungus sub-lethal concentrations were done using a $\chi^{2}$ goodness-of-fit test.
Entropy was used as a criterion for determining the direction of curvature of survivor curves:

$$
H=\frac{\sum_{x=0}^{w} e_{x} d_{x}}{e_{0}}
$$

where $H$ is the entropy value, $x$ is denoted age, $w$ is the final age of cohort, $e$ is life expectancy, and $d$ is age-specific mortality. An entropy value of 0.5 implies a linear survival $\left(l_{x}\right)$ schedule, whereas a lesser value and a greater value, respectively, imply the convex and concave curve shape of the $l_{x}$ schedule.

\section{Results and discussion}

The results of bioassays with M. anisopliae (DEMI 001 strain) on third-instar larvae of T. absoluta are presented in Table 1. The estimated value of $\mathrm{LC}_{50}$ and $\mathrm{LC}_{90}$, based on the mortality trends across concentration after 8 days, were $1.37 \times 10^{5}\left(7.54 \times 10^{4}-2.35 \times 10^{5}\right.$ conidia $\left.\mathrm{ml}^{-1}\right)$ and $1.45 \times 10^{7}\left(5.44 \times 10^{6}-5.91 \times 10^{7}\right.$ conidia $\left.\mathrm{ml}^{-1}\right)$, respectively, while no mortality was recorded in controls. These findings indicate that M. anisopliae (isolate DEMI 001) had pathogenic and virulence effects on third-instar larvae of $T$. absoluta. The results are in consistency with the reports of (Inanl and Oldargc 2012; Tadels and Emana 2017; and Nozad-Bonab et al. 2017).

Table 2 Life history parameters (mean \pm SE) of Tuta absoluta treated with different sub-lethal concentrations of Metarhizium anisopliae (DEMI 001 strain)

\begin{tabular}{lllll}
\hline Developmental time & Treatments & & & \\
\cline { 2 - 5 } & Control & $4 C_{10}$ & $L C_{20}$ & \\
\hline Egg (days) & $4.35 \pm 0.06 \mathrm{~b}$ & $4.41 \pm 0.09 \mathrm{ab}$ & $4.55 \pm 0.14 \mathrm{ab}$ & $4.74 \pm 0.13 \mathrm{a}$ \\
Larvae (days) & $10.82 \pm 0.21 \mathrm{~b}$ & $10.88 \pm 0.27 \mathrm{~b}$ & $11.05 \pm 0.29 \mathrm{~b}$ & $12.51 \pm 0.37 \mathrm{a}$ \\
Pupa (days) & $7.51 \pm 0.21 \mathrm{c}$ & $8.04 \pm 0.21 \mathrm{bc}$ & $8.45 \pm 0.22 \mathrm{ba}$ & $8.97 \pm 0.22 \mathrm{a}$ \\
Total immature (days) & $22.68 \pm 0.33 \mathrm{c}$ & $23.32 \pm 0.33 \mathrm{cb}$ & $24.05 \pm 0.37 \mathrm{~b}$ & $26.23 \pm 0.40 \mathrm{a}$ \\
Pre-oviposition (days) & $1.70 \pm 0.34 \mathrm{a}$ & $1.83 \pm 0.32 \mathrm{a}$ & $1.95 \pm 0.38 \mathrm{a}$ & $1.65 \pm 0.34 \mathrm{a}$ \\
Oviposition (days) & $12.57 \pm 0.73 \mathrm{a}$ & $11.56 \pm 0.22 \mathrm{a}$ & $7.85 \pm 0.61 \mathrm{~b}$ & $6.76 \pm 0.73 \mathrm{~b}$ \\
Post-oviposition (days) & $3.83 \pm 0.58 \mathrm{a}$ & $4.17 \pm 0.53 \mathrm{a}$ & $4.30 \pm 0.58 \mathrm{a}$ & $4.12 \pm 0.61 \mathrm{a}$ \\
Fecundity- total (eggs) & $129.87 \pm 2.48 \mathrm{a}$ & $122.78 \pm 2.33 \mathrm{a}$ & $106.65 \pm 7.85 \mathrm{ab}$ & \\
Female longevity (days) & $18.09 \pm 1.64 \mathrm{a}$ & $17.56 \pm 1.10 \mathrm{a}$ & $14.10 \pm 0.83 \mathrm{ab}$ & $12.71 \pm 8.29 \mathrm{~b}$ \\
Male longevity (days) & $16.74 \pm 1.00 \mathrm{a}$ & $16.33 \pm 1.04 \mathrm{a}$ & $12.53 \pm 1.19 \mathrm{~b}$ \\
\hline
\end{tabular}

Means $( \pm$ SE) in a row followed by the same letters are not significantly different using Student-Newman-Keuls test (SNK) 
Table 3 Sub-lethal effects of Metarhizium anisopliae (DEMI 001 strain) on sex ratio of Tuta absoluta tested by $x^{2}$ goodness-of-fit to a 1:1 (female to male) ratio

\begin{tabular}{|c|c|c|c|c|c|c|c|}
\hline \multirow[t]{2}{*}{ Treatments } & \multicolumn{2}{|c|}{ Observed frequency ${ }^{a}$} & \multicolumn{2}{|c|}{ Expected frequency } & \multirow{2}{*}{$\begin{array}{l}x^{2} \\
\text { (df }= \\
1)\end{array}$} & \multirow{2}{*}{$\begin{array}{l}P \\
\text { value }\end{array}$} & \multirow{2}{*}{$\begin{array}{l}\text { Female } \\
\text { to male }\end{array}$} \\
\hline & Female & Male & Female & Male & & & \\
\hline Control & 38 & 27 & 32.5 & 32.5 & 1.862 & 0.172 & 1.41 \\
\hline $\mathrm{LC}_{10}$ & 31 & 25 & 28 & 28 & 0.643 & 0.423 & 1.24 \\
\hline $\mathrm{LC}_{20}$ & 24 & 20 & 22 & 22 & 0.364 & 0.546 & 1.20 \\
\hline $\mathrm{LC}_{30}$ & 18 & 20 & 19 & 19 & 0.105 & 0.746 & 0.90 \\
\hline
\end{tabular}

${ }^{a}$ The numbers of adults used to calculate the observed sex ratio for Tuta absoluta at control, $\mathrm{LC}_{10}, \mathrm{LC}_{20}$, and $\mathrm{LC}_{30}$ treatments was $65,56,44$, and 38, respectively

Duration of egg to adult emergence of $T$. absoluta offspring resulted from third-instar larvae treated with different sub-lethal concentrations $\left(\mathrm{LC}_{10}, \mathrm{LC}_{20}\right.$, and $\mathrm{LC}_{30}$ ) of $M$. anisopliae (isolate DEMI 001) are presented in Table 2. The sub-lethal concentration had significant effects on embryonic development $(F=2.722 ; \mathrm{df}=3,200$; $P<0.05)$, larval stage $(F=7.147 ; \mathrm{df}=3,200 ; P<0.001)$, pupal $(F=8.068 ; \mathrm{df}=3,200 ; P<0.001)$, and total developmental time $(F=16.791 ; \mathrm{df}=3,200 ; P<0.001)$. The longest and shortest period of total immature stages were observed at $\mathrm{LC}_{30}$ and control treatment, respectively. According to the present study, infection of larvae with a sub-lethal concentration of $M$. anisopliae (isolate DEMI 001) reduced the fitness by affecting different biological parameters of offspring in ensuing generation. Also, results showed that the total developmental time (egg to adult emergence) of a subsequent generation of T. absoluta increased in all treatments $\left(\mathrm{LC}_{10}, \mathrm{LC}_{20}\right.$, and $\mathrm{LC}_{30}$ ) and was different than control treatment. This result is in consistency with the studies conducted by Jarrahi and Safavi (2016) who reported that sub-lethal concentrations of $M$. anisopliae s.l. (isolate M14) protracted immature stages of the cotton bollworm, Helicoverpa armigera ( $\mathrm{Hb}$.), in the $\mathrm{F} 1$ generation. On the contrary, Kaur et al. (2011) stated that B. bassiana (PDBC-Bb-5a) decreased the larval period of

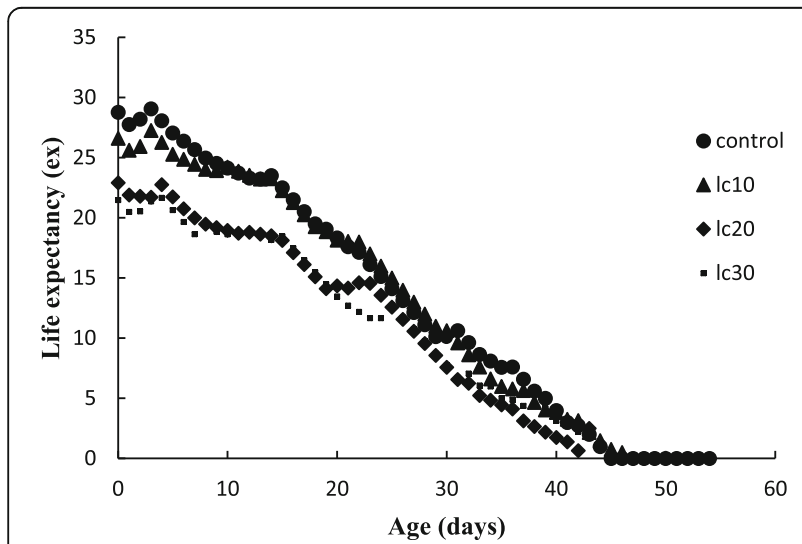

Fig. 1 Life expectancy $\left(e_{x}\right)$ of Tuta absoluta treated with different sub-lethal concentrations of Metarhizium anisopliae (DEMI 001 strain)
Spodoptera litura (Fabricius) (Lepidoptera: Noctuidae). In biological control programs, protracted immature stages of an insect are important, since the developmental time of the pest is long and the exposure to natural enemies (parasitoids and predators) could probably increase (Price 1997).

Longevity of the emerged adult females $(F=4.305 ; \mathrm{df}=$ 3, 74; $P=0.007)$, males $(F=4.906 ; \mathrm{df}=3,74 ; P=0.004)$, the ovipositional periods $(F=8.526 ; \mathrm{df}=3,74 ; P<0.001)$, and the total fecundity $(F=3.732 ; \mathrm{df}=3,74 ; P<0.05)$ were significantly affected by sub-lethal concentrations than the control. However, fungal infection had insignificant effects on pre-ovipositional $(F=0.150 ; \mathrm{df}=3,74 ; P=0.930)$ and post-ovipositional $(F=0.133 ; \mathrm{df}=3,74 ; P=0.940)$ periods of $T$. absoluta in the subsequent generation (Table 2). The present research revealed that the application of sub-lethal concentration of $M$. anisopliae (isolate DEMI 001) reduced the longevity of moth adults (female and males) in all treatment schedules. Furthermore, the utilization of sub-lethal concentrations of the fungus significantly affected the progeny production of the tomato leaf miner in offspring. Females emerged from treated larvae had significantly lower reproductive fitness than the control. Moreover, female total fecundity range was estimated from (129.87 to 85.71) eggs in control and $\mathrm{LC}_{30}$, respectively. Similarly, adult emergence rate, longevity, and fecundity capacity of $S$. litura were decreased by concentration-dependent of B. bassiana (Kaur et al. 2011). Likewise, in findings similar to the obtained data, Ekesi and Maniania (2000) reported that M. anisopliae strain ICIPE 69 treatment reduced fitness of Megalurothrips sjostedti adults surviving infection as larvae. It has been documented that sub-lethal concentration of fungus can affect reproduction capacity of infected insects (Mulock and Chandler 2001). Thus, it is possible to mention that an increase in conidial concentration resulted in decreasing the reproductive fitness and increasing pathogen fitness by diverting host resources such as energy to the pathogen (Roy et al. 2006). Furthermore, the reduction in the progeny of females could result from the reduction in adult longevity arising from treated larvae.

Moreover, the observed values of sex ratio of T. absoluta had an insignificant deviation from the expected ratio of 
Table 4 Mean ( \pm SE) life table parameters of Tuta absoluta treated with different sub-lethal concentrations of Metarhizium anisopliae (DEMI 001 strain)

\begin{tabular}{lllll}
\hline Parameters & Treatments & & & \\
\cline { 2 - 5 } & Control & $L C_{10}$ & $L C_{20}$ & $L C_{30}$ \\
\hline Net reproductive rate $\left(R_{0}\right)$ (offspring) & $49.35 \pm 0.24 \mathrm{a}$ & $38.07 \pm 0.19 \mathrm{~b}$ & $25.59 \pm 0.10 \mathrm{c}$ & $15.43 \pm 0.09 \mathrm{c}$ \\
Gross reproduction rate $(\mathrm{GRR})$ (offspring) & $150.28 \pm 0.54 \mathrm{a}$ & $130.52 \pm 0.47 \mathrm{ab}$ & $113.39 \pm 0.51 \mathrm{ab}$ & $96.85 \pm 0.70 \mathrm{~b}$ \\
Intrinsic rate of increase $\left(r_{m}\right)\left(\right.$ day $\left.^{-1}\right)$ & $0.140 \pm 0.0002 \mathrm{a}$ & $0.130 \pm 0.0003 \mathrm{~b}$ & $0.113 \pm 0.0001 \mathrm{c}$ & $0.087 \pm 0.0002 \mathrm{~d}$ \\
Finite rate of increase $(\lambda)\left(\right.$ day $\left.{ }^{-1}\right)$ & $1.15 \pm 0.0002 \mathrm{a}$ & $1.14 \pm 0.0003 \mathrm{~b}$ & $1.12 \pm 0.0002 \mathrm{c}$ & $1.09 \pm 0.0002 \mathrm{~d}$ \\
Mean generation time $(T)($ day) & $27.84 \pm 0.01 \mathrm{a}$ & $28.01 \pm 0.04 \mathrm{a}$ & $28.68 \pm 0.02 \mathrm{a}$ & $30.15 \pm 0.03 \mathrm{~b}$ \\
Doubling time $($ day) & $4.95 \pm 0.01 \mathrm{a}$ & $5.33 \pm 0.01 \mathrm{a}$ & $6.13 \pm 0.01 \mathrm{~b}$ & $7.64 \pm 0.01 \mathrm{c}$ \\
\hline
\end{tabular}

Means $( \pm$ SE) in a row followed by the same letters are not significantly different using Student-Newman-Keuls test (SNK)

1:1 (Table 3). The larvae treated with the sub-lethal concentration had no effect on the sex ratio of offspring.

Survivorship of the immature stages of progeny derived from treated larvae of T. absoluta was $0.56,0.44$, 0.38 , and $0.65 \%$ at $\mathrm{LC}_{10}, \mathrm{LC}_{20}, \mathrm{LC}_{30}$, and control, respectively. The life expectancy (the lifespan that an individual in age $x$ is expected to live) of 1-day-old females of the T. absoluta was $16.13,17,13.6$, and 11.73 days at control, $\mathrm{LC}_{10}, \mathrm{LC}_{20}$, and $\mathrm{LC}_{30}$, respectively (Fig. 1 ). The value of entropy parameter $(H)$ of $T$. absoluta was 0.39 , $0.47,0.51$, and $0.58 \%$ in control and other treatments $\left(\mathrm{LC}_{10}, \mathrm{LC}_{20}\right.$, and $\left.\mathrm{LC}_{30}\right)$, respectively. The entropy values, as a quantitative characterization of survival pattern, indicated that the survival schedule of $T$. absoluta was convex $(H<0.5)$ at control and $\mathrm{LC}_{10}$ and corresponded to type I survivorship curves with low mortality levels in early developmental stages. However, the survival schedule of $\mathrm{LC}_{20}$ and $\mathrm{LC}_{30}$ was a concave curve $(H>0.5)$, with low mortality levels in late ages. Maximum life expectancy (at birth, $x=0$ ) was 28.76, 26.62, 22.92, and 22.30 days at control, $\mathrm{LC}_{10}, \mathrm{LC}_{20}$, and $\mathrm{LC}_{30}$, respectively.

Values of the intrinsic rate of increase $\left(r_{m}\right) \quad(F=$ $26.759 ; \mathrm{df}=3,74 ; P<0.0001)$, the net reproductive rate $\left(R_{0}\right)(F=16.607 ; \mathrm{df}=3,74 ; P<0.0001)$, the gross reproduction rate $(\mathrm{GRR})(F=4.279 ; \mathrm{df}=3,74 ; P=$ $0.008)$, and the finite rate of increase $(\lambda)(F=26.289$; $\mathrm{df}=3,74 ; P<0.0001)$ were significantly affected by sub-lethal treatments with $M$. anisopliae (isolate

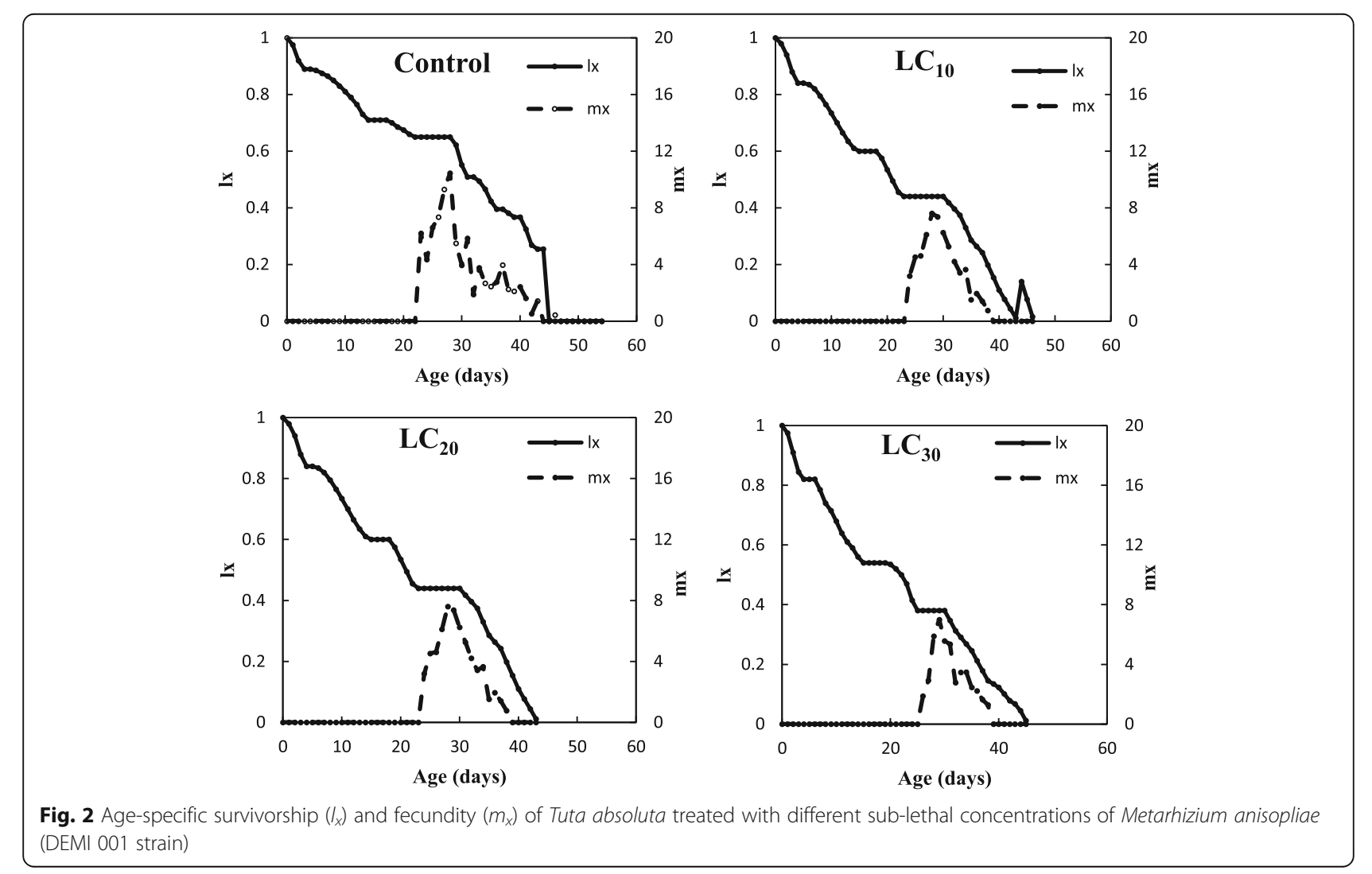


DEM 001) and decreased than the control (Table 4). However, the mean generation time $(T)$ and doubling time of T. absoluta (DT) increased in sub-lethal concentration $(F=2.742 ; \mathrm{df}=3,74 ; P<0.049$ and $F=$ 35.602; $\mathrm{df}=3,74 ; P<0.0001$, respectively). The highest GRR were observed in control treatment $(87.85$ generations per female).

Age-specific survivorship $\left(l_{x}\right)$ and age-specific fecundity $\left(m_{x}\right)$ of $T$. absoluta at different treatments are presented in Fig. 2. The highest (0.65\%) and lowest $(0.38 \%)$ survivorships of immature stages (from egg to adult) were recorded at control and $\mathrm{LC}_{30}$, respectively.

The results revealed that the life table parameters of $T$. absoluta in the F1 generation were significantly affected by the sub-lethal concentration of $M$. anisopliae (isolate DEMI 001). The reproductive rate included the gross fecundity rate (GRR) and the net fecundity rate $\left(R_{0}\right)$ values that decreased significantly in all treatments than the control. $\mathrm{LC}_{30}$ caused a three-time decline in $R_{0}$ value compared to control. Accordingly, the intrinsic rate of increase $\left(r_{m}\right)$ and the finite rate of increase $(\lambda)$ values decreased in the following generation of $T$. absoluta, while the mean generation time $(T)$ and doubling time (DT) increased in the treatments $\left(T=\frac{\ln R_{0}}{r} ; \mathrm{DT}=\frac{\ln 2}{r}\right)$.

The lower $r_{m}$ in the sub-lethal treatments compared to control highlighted the adverse effects of $M$. anisopliae (isolate DEMI 001) on the population growth of pest. The intrinsic rate of increase $\left(r_{m}\right)$ is a good criterion of responses of insects to toxicants, as well as a parameter to describe population growth rate (Forbes and Calow 1999). In $\mathrm{LC}_{30}$, the high generation time, the low fecundity, and survival perhaps cause a decrease in $r_{m}$ compared to control. Moreover, vulnerability to sub-lethal concentrations of $M$. anisopliae increased the mean generation time $(T)$, causing a decrease in $r_{m}$ and $R_{0}$ values of $H$. armigera progeny (Jarrahi and Safavi 2016).

\section{Conclusion}

Obtained findings suggest that $M$. anisopliae (isolate DEMI 001) had the potential for biological control of $T$. absoluta. Sub-lethal concentration, in the following generations of T. absoluta, arose from parental generations that its third-instar larvae treated by the fungus resulted in a reduction in fitness by both decreasing longevity and fecundity. As well, it decreased the population increase parameters. Studying the effects of environmental conditions (such as temperature) on the virulence of the strain is necessary to be conducted under field and greenhouse conditions. Subsequently, the deleterious effects on the characterization behavior of parasitoid and predators released in tomato fields after application of this pathogen such as predation or parasitism rate and preference need to be determined.

\section{Acknowledgements}

This research was supported by the Department of Plant Protection, University of Urmia, Urmia, Iran, which is greatly gratitude.

Funding

There is no funding source to be declared for this study.

Availability of data and materials

All data generated or analyzed during this study are included in this published article.

\section{Authors' contributions}

The authors contribute equally in this research. All authors read and approved the final manuscript.

Ethics approval and consent to participate Not applicable.

\section{Consent for publication}

All authors read and approved the final manuscript and are consent to this publication.

\section{Competing interests}

The authors declare that they have no competing interests.

\section{Publisher's Note}

Springer Nature remains neutral with regard to jurisdictional claims in published maps and institutional affiliations.

\section{Author details}

${ }^{1}$ Department of Plant Protection, Faculty of Agriculture, Urmia University, Urmia, Iran. ${ }^{2}$ Department of Plant Protection, Faculty of Agriculture, University of Tabriz, Tabriz, Iran.

Received: 18 December 2018 Accepted: 8 March 2019

Published online: 10 April 2019

\section{References}

Batalla-Carrera L, Morton L, García-del-Pino F (2010) Efficacy of entomopathogenic nematodes against the tomato leafminer Tuta absoluta in laboratory and greenhouse conditions. BioControl 55:523-530

Birch LC (1948) The intrinsic rate of natural increase an insect population. J Anim Ecol 17:15-26

Blanford S, Thomas M (2001) Adult survival, maturation, and reproduction of the desert locust Schistocerca gregaria infected with the fungus Metarhizium anisopliae var acridum. J Invertebr Pathol 78:1-8

Butt TM, Jackson C, Magan N (2001) Fungi as biocontrol agents: progress, problems and potential. CABI International, Wallingford

Carey JR (1993) Applied demography for biologists with special emphasis on insects. Oxford University Press, United Kingdom, p 224

Contreras J, Mendoza JE, Martinez-Aguirre MR, Garcia-Vidal L, Izquierdo J, Bielza P (2014) Efficacy of enthomopathogenic fungus Metarhizium anisopliae against Tuta absoluta (Lepidoptera: Gelechiidae). J Econ Entomol 107:121-124

Ekesi S, Maniania NK (2000) Susceptibility of Megalurothrips sjostedti developmental stages to Metarhizium anisopliae and the effects of infection on feeding, adult fecundity, egg fertility and longevity. Entomol Exp Appl 94:229-236

Finney DS (ed) (1971) Probit Analysis. University Press, Cambridge, p 333

Forbes VE, Calow P (1999) Is the per capita rate of increase a good measure of population-level effects in ecotoxicology? Environ Toxicol Chem 18:1544-1556

Giustolin TA, Vendramim JD, Alves SB, Vieira SA, Pereira RM (2001) Susceptibility of Tuta absoluta (Meyrick) (Lep., Gelechiidae) reared on two species of Lycopersicon to Bacillus thuringiensis subsp. kurstaki. J Appl Entomol 125:551-556

Goettel MS, Eilenberg J, Glare TR (2005). Entomopathogenic fungi and their role in regulation of insect populations. In: Gilbert LI, latrou K, Gill S (eds) Comprehensive molecular insect science, Hendrichs J, Ortiz G, Liedo P, Schwarz A (1983) Six years

González-Cabrera J, Mollá O, Montón H, Urbaneja A (2011) Efficacy of Bacillus thuringiensis (Berliner) in controlling the tomato borer, Tuta absoluta (Meyrick) (Lepidoptera: Gelechiidae). BioControl 56:71-80 
Hajek AE, Lund J, Smith MT (2008) Reduction in fitness of female Asian longhorned beetle (Anoplophora glabripennis) infected with Metarhizium anisopliae. J Invertebr Pathol 98:198-205

IBM Corp (2016). IBM SPSS Statistics for Windows, version 24.0. IBM Corp. Armonk, New York

Inanl C, Oldargc AK (2012) Effects of entomopathogenic fungi, Beauveria bassiana (Bals.) and Metarhizium anisopliae (Metsch.) on larvae and egg stages of Tuta absoluta (Meyrick) Lepidoptera: Gelechiidae. Ege Üniversitesi Ziraat Fakültesi Dergisi 49:239-242

Inglis GD, Enkerli J, Goettel MS (2012) Laboratory techniques used for entomopathogenic fungi: hypocreales. In: Lacey LA (ed) Manual of techniques in invertebrate pathology. Academic Press, San Diego, pp 189-253

Jarrahi A, Safavi SA (2016) Fitness costs to Helicoverpa armigera after exposure to sub-lethal concentrations of Metarhizium anisopliae Sensu Lato: study on F1 generation. J Invertebr Pathol 138:50-56

Kaur S, Kaur HP, Kaur K, Kaur A (2011) Effect of different concentrations of Beauveria bassiana on development and reproductive potential of Spodoptera litura (Fabricius). J Biopest 4:161-168

Lee MS, Albajes R, Eizaguirr M (2014) Mating behavior of female Tuta absoluta (Lepidoptera: Gelechiidae): polyandry increases reproductive output. J Pest Sci 87:429-439

Maia AHN, Luiz AJB, Campanhola C (2000) Statistical influence on associated fertility life table parameters using jackknife technique, computational aspects. J Econ Entomol 93:511-518

Mulock BS, Chandler LD (2001) Effect of Beauveria bassiana on the fecundity of western corn rootworm, Diabrotica virgifera virgifera (Coleoptera: Chrysomelidae). BioControl 22:16-21

Nozad-Bonab Z, Hejazi MJ, Iranipour S, Arzanlou M (2017) Lethal and sublethal effects of some chemical and biological insecticides on Tuta absoluta (Lepidoptera: Gelechiidae) eggs and neonates. J Econ Entomol 110:1138-1144

Pires L, Marques E, Wanderley-Teixeira V, Teixeira Á, Alves L, Alves E (2009) Ultrastructure of Tuta absoluta parasitized eggs and the reproductive potential of females after parasitism by Metarhizium anisopliae. Micron 40:255-261

Price PW (1997) Insect ecology, 3rd edn. Wiley, New York

Roberts DW, St Leger RJ (2004) Metarhizium spp., cosmopolitan insect-pathogenic fungi: mycological aspects. Adv Appl Microbiol 54:1-70

Roy HE, Steinkraus DC, Eilenberg J, Hajek AE, Pell JK (2006) Bizarre interactions and endgames: entomopathogenic fungi and their arthropod hosts. Annu Rev Entomol 51:331-357

Tadele S, Emana G (2017). Entomopathogenic Effect of Beauveria bassiana (Bals.) and Metarrhizium anisopliae (Metschn.) on Tuta absoluta (Meyrick) (Lepidoptera: Gelechiidae) larvae under laboratory and glasshouse conditions in Ethiopia. J Plant Pathol Microbiol 8: 411-414.

Tropea-Garsia G, Siscaro G, Biondi A, Zappala L (2012) Tuta absoluta, an exotic invasive pest from South America now in the EPPO region: biology, distribution and damage. EPPO Bulletin 42:205-210

Tuan SJ, Yeh CC, Atlihan A, Chi H (2015) Linking life table and predation rate for biological control: a comparative study of Eocanthecona furcellata (Hemiptera: Pentatomidae) fed on Spodoptera litura (Lepidoptera: Noctuidae) and Plutella xylostella (Lepidoptera: Plutellidae). J Econ Entomol (1):13

Urbaneja A, González-Cabrera J, Arnó J, Gabarra R (2012) Prospects for biological control of Tuta. absoluta in tomatoes of the Mediterranean basin. Pest Manag Sci 68:1215-1222

Zappala L, Biondi A, Alma A, Al-Jboory IJ, Arno J, Bayram A, Chailleux A, ElArnaouty A, Gerling D, Guenaoui Y, Shaltiel-Harpaz L, Siscaro G, Stavrinides M, Tavella L, Aznar RV, Urbaneja A, Desneux N (2013) Natural enemies of the South American moth, Tuta absoluta, in Europe, North Africa and Middle East, and their potential use in pest control strategies. J Pest Sci 86:635-647

Zimmermann G (1993) The entomopathogenic fungus Metarhizium anisopliae and its potential as a biocontrol agent. Pestic Sci 37:375-379

\section{Submit your manuscript to a SpringerOpen ${ }^{\circ}$ journal and benefit from:}

- Convenient online submission

- Rigorous peer review

- Open access: articles freely available online

- High visibility within the field

- Retaining the copyright to your article

Submit your next manuscript at $\boldsymbol{\nabla}$ springeropen.com 